Volume 9

Issue 2 Time, Movement, and Space: Genocide

Studies and Indigenous Peoples

$10-2015$

\title{
Killing Them Softly: Forcible Transfers of Indigenous Children
}

Ruth Amir

Yezreel Valley College

Follow this and additional works at: https://digitalcommons.usf.edu/gsp

\section{Recommended Citation}

Amir, Ruth (2015) "Killing Them Softly: Forcible Transfers of Indigenous Children," Genocide Studies and Prevention: An International Journal: Vol. 9: Iss. 2: 41-60.

DOI:

http://dx.doi.org/10.5038/1911-9933.9.2.1289

Available at: https://digitalcommons.usf.edu/gsp/vol9/iss2/7

This Articles is brought to you for free and open access by the Open Access Journals at Digital Commons @ University of South Florida. It has been accepted for inclusion in Genocide Studies and Prevention: An International Journal by an authorized editor of Digital Commons @ University of South Florida. For more information, please contact digitalcommons@usf.edu. 


\title{
Killing Them Softly: Forcible Transfers of Indigenous Children
}

\author{
Ruth Amir \\ Yezreel Valley College \\ Emek Yezreel, Israel
}

\begin{abstract}
The forcible transfer of indigenous children in North America and Australia are part of a global phenomenon that consisted of the kidnapping, trafficking, removal, and identity changes of children of particular groups.

Article II(e) of the United Nation Convention on the Prevention and Punishment of Genocide (UNGC) prohibits the forcible transfer of children of a group to another group (FTC). The FTC echoes domestic and international legal norms and policies for the protection of children since early twentieth century. Its particular applicability to specific victims within a protected group - children - conveys a unique ethical position compared to the other acts enumerated acts in Article II, and the UNGC as a whole. This uniqueness may justify the much needed conceptual leap from the legalistic western-biased notion of genocide towards a more inclusive recognition of the political, social, and economical aspects of genocide.
\end{abstract}

Keywords: forcible transfers of children, genocide, Article II(e) of the UNGC, patient-specific deontological reasoning, Aboriginal residential schools

\section{Introduction}

Article II (e) of The United Nations Convention of the Prevention and Punishment of Genocide (UNGC) prohibits the forcible transfer of children (FTC) from one group to another. ${ }^{1}$ The FTC has received scant attention by genocide scholars and is generally considered a legal anachronism. ${ }^{2}$ William Schabas wrote that the FTC is enigmatic since the drafters excluded cultural genocide from the UNGC, and that it was passed "almost as an afterthought." 3

This article focuses on the forcible transfers of Indigenous children in North America and Australia to residential schools. These transfers are part of a wider, global phenomenon of the kidnapping, trafficking, removal, and identity changes of children of particular groups. Forcible transfers of children had begun in the eighteenth century but peaked in the twentieth century. ${ }^{4}$ Yet, despite its global scope, this practice has remained largely understudied as a phenomenon. ${ }^{5}$

In recent years, scholars have asserted that the UNGC can be applied to cases of forcible transfer of Indigenous children to residential schools. ${ }^{6}$ Survivors have also related to their experiences in terms of genocide. ${ }^{7}$ Yet, residential schools litigation has faced substantial legal obstacles in both domestic and international law regardless of whether they seek to apply the UNGC or tort law. ${ }^{8}$

The first section analyzes the origins of the FTC, its ethical uniqueness as a victim-centered deontological and consequentialist ethic, and its legislative history. The second discusses the difficulties of applying the FTC with respect to the type of protected groups and the onus of the proof of special intent. Section three discusses the modernist notions of childhood that target children in general and Aboriginal children in particular. The fourth section analyzes the forcible transfers of Indigenous children in the United States, Canada, and Australia to residential schools. The three cases share the primarily British colonialism as a framework. Each country sub-section offers a brief history of the case, the onset of the schools in the nineteen century, major legislation, and policy-makers reports. It also offers a brief overview of some case law and its limitations. The paper concludes with the discussion of the cases and the implications towards a much needed opening up of the UNGC for addressing the harms caused by the forcible transfers.

\section{The FTC: Origins, Ethical Uniqueness, and Legislative History \\ Origins}

The FTC echoes domestic and international legal norms and policies for the protection of children since early twentieth century. By the first half of the twentieth century these norms had achieved legal validation in state and international law that warranted the FTC's inclusion in the UNGC. ${ }^{9}$ 
The FTC trails the League of Nations' humanitarian field-work and customary law provisions. The goal of the League's Commission on Women and Children in the Near East was to rescue and rehabilitate Armenian children. Its special committee had adopted conventions prohibiting the traffic in women and children in 1921, and slavery in $1926 .{ }^{10}$

The 1924 Geneva Declaration of the Rights of the Child adopted by the League's Assembly states in Article 1 that "[t]he child must be given the means requisite for its normal development, both materially and spiritually". ${ }^{11}$ However, it failed to define the age under which a person is considered a child. ${ }^{12}$ The Declaration's subsequent articles concerned physical and material provisions, priority in relief, protection against exploitation and the collectivist notion of the child as future contributor to society. ${ }^{13}$

Post-WWII humanitarian efforts targeted the psychological rehabilitation of displaced children in general and the mitigation of psychological suffering and dislocation in particular. ${ }^{14}$ Hence, the separation of children from their parents was recognized as the cause of trauma. ${ }^{15}$

The FTC echoes the Nuremberg Military Tribunal ruling that established the kidnapping of Eastern European Children as particularly severe and unacceptable for the international community, and considered these practices as genocide. ${ }^{16}$ The opening statement of prosecutor McHaney referred to Lemkin's Axis Rule. ${ }^{17}$ Prosecutor Shiller's closing statement described the Nazi practices of cultural genocide. ${ }^{18}$ Forcible transfers of children were also tried in Poland's Supreme National Tribunal and Britain's Military Court. ${ }^{19}$

\section{Ethical Uniqueness}

The FTC's applicability to specific victims within a protected group - children - seems to convey a distinctive ethical position vis-à-vis the Article II clauses a-d, and the UNGC as a whole. ${ }^{20}$ Moral theories are generally classified as either deontological or consequentialist, and UNGC like the common sense morality of western culture is substantially deontological. ${ }^{21}$ Most deontological theories hold that some choices are morally wrong and cannot be justified by their effects. Hence an act or a choice is right if it obeys a moral norm, and an action's motive can determine whether or not that action is right or wrong. ${ }^{22}$ Consequentialism, in turn, presupposes "the Good," namely the states of affairs that are intrinsically valuable. It posits that right actions or institutions are those that maximize the intrinsically good states of affairs and minimize the bad ones. ${ }^{23}$ The most common consequentialist view is classic utilitarianism, where consequentialism is often taken as a general principle of practical rationality and "the Good" is often defined in utilitarian terms. ${ }^{24} \mathrm{In}$ A Theory of Justice John Rawls argues that "[u]tilitarianism does not take seriously the distinction between persons," and does not weigh directly justice and fairness considerations. ${ }^{25}$ However, other scholars argue that consequentialism does indeed take an explicit account of justice. ${ }^{26}$

Deontological theories are further divided into at least three types, namely, victim-centered, agent-centered, and combined theories. ${ }^{27}$ Victim-centered deontological theories are premised on the rights of persons. ${ }^{28} \mathrm{Kamm}$ 's victim-centered approach considers "what the victim lost was what he would have had independently of the agent" ${ }^{29}$ In contradistinction, agent-centered theories focus on permissions and obligations of each individual. These provide the individual with agentrelative reasons for action. Some agent-centered theories focus on the role of intention or other mental states in constituting the morally important kind of agency, such as the specific intent, and those that emphasize agents' actions. ${ }^{30}$ Others emphasize both intentions and actions equally in constituting the morally relevant agency of persons.

While the FTC suggests a victim-centered deontological ethic, it also deviates from deontological ethics by being rights-based rather than duty-based. Rights-based ethics suggests that all humans have that some rights, both positive and negative, that are natural or conventional, constant and undeniable. ${ }^{31}$ Whereas natural rights are moral, conventional rights are created by humans and reflect society's values. Rights-based ethics stands in contradistinction to the deontological dutybased and intention-based agent-centered ethic of the UNGC in general and Articles II (a-d) in particular.

Lemkin's fingerprints are evident in the victim-specificity of the FTC. His compassion for children is evident in his writings. His 1944 article "Orphans of Living Parents" deals with children of divorced couples and compares various conceptions of the family. ${ }^{32}$ His comparative study on 
the proper treatment of young offenders in corrective facilities highlights the potential effect of the educators on the inmates' future..$^{33}$

The losses of the forcibly transferred children and their rights provide the moral constraint against the agents' attempted act for achieving a "good" cause, or using the children for their own benefit. This is reflected in Prosecutor Neely's words in the United States v. Greifelt, at Nuremberg:

[I]t is no defense for a kidnapper to say he treated his victim well... these innocent children were abducted for the very purpose of being indoctrinated with Nazi ideology and brought up as "good" Germans. This serves to aggravate, not mitigate, the crime. ${ }^{34}$

Neely's victim-based approach is closely linked to the consequences of the transfer. Forcible transfers of children have dire, long term consequences. Thus, in Totally Unofficial Lemkin uses consequentialist argumentation to illustrate the long-term horrendous effect of forcible transfers: "Greece... a nation of seven million, would have a population of sixteen million if not for the Greek children who were taken away for four hundred years." ${ }^{35}$

The FTC's ethical uniqueness is therefore twofold. First, it is rights-based victim-specific whereas the remaining clauses of Article II of the UNGC are universal. Second, and more importantly, the FTC incorporates consequential reasoning into its deontological framework.

\section{Legislative History}

The FTC's legislative history clearly conveys the FTC's ethical uniqueness. The Secretariat draft Convention dated March 28, 1947, prepared by the Social and Economic Council included the FTC in Article 3(a) that enumerated acts intended to destroy the specific characteristic of a group. ${ }^{36}$ The comments section of UN Document E/447 states:

The separation of children from their parents results in forcing upon the former at an impressionable and receptive age a culture and mentality different from their parents'. This process tends to bring about the disappearance of the group as a cultural unit in a relatively short time. ${ }^{37}$

These words clearly convey a victim-centered ethic coupled with consequentialism. The Draft recognizes childhood as a receptive age, and children as more susceptible to influence than adults. The Ad-Hoc Committee's boisterous deliberations resulted in a draft convention that was submitted to the General Assembly's Sixth Committee (Legal). ${ }^{38}$ This draft however, omitted the FTC.

The FTC was retrieved at the 81st meeting of the Sixth Committee by the Greek Delegate, Jean Spiropoulos. ${ }^{39}$ Most of the discussion that took place at the $82^{\text {nd }}$ meeting concerned the effect of forcible transfers of children on the continuity of groups. ${ }^{40}$ The delegates' arguments for the inclusion of the FTC were twofold. First, the victim-specific characteristics of children, namely, dependence, futurity, and malleability rendered them valuable for the perpetrators. Second, the drafters highlighted the devastating consequences of this practice and its long-term hindering of the existence of a group. These justifications are also found in Lemkin's Totally Unofficial. ${ }^{41}$ John Maktos, the U.S. delegate argued that forcible transfers of children of particular groups were a form of physical or biological genocide. ${ }^{42}$ Similarly, Vallindas, the Greek delegate, denied that Article II(e) disassociated forcible transfers of children from the controversial cultural genocide. Vallindas highlighted the consequences of FTC, namely the destruction of a group, that is, physical genocide. ${ }^{43}$

Donnedieu de Vabres suggested that the forcible transfer of children was an act far more barbarous than those enumerated under cultural genocide. ${ }^{44}$ His words justify the constitution of this victim-specific provision intended to protect children from the devastating consequences of forcible transfers. In de Vabres' words: "The forced transfer of children had not only cultural, but also physical and biological effects since it imposed on young persons' conditions of life likely to cause them serious harm or even death." ${ }^{45}$ The Uruguayan delegate also endorsed the FTC's victim-specificity. He argued that forcible transfers of children were "intended to destroy a new 
generation through abducting infants, forcing them to change their religion and educating them to become enemies of their own people". ${ }^{46}$

The strongest verbalization of the victim-centered ethic was the delegates' response to the proposal put forward by the Syrian delegate, Salah El Line Tarazi. Tarazi proposed to include among the acts constituting genocide the forcible removal of members of a group from their homes, based on the events of WWII. ${ }^{47}$ Opposition to this provision focused mainly on the allegedly unduly widening of the scope of the convention. The Soviet delegate Platoon Morozov was opposed to both the Greek and Syrian amendments. He argued that both "went far beyond the limits of the provisions already accepted under article $\mathrm{II}^{\prime \prime}{ }^{48}$ He further argued that from the historical point of view none of the forcible transfers of children and young people constituted genocide. ${ }^{49}$ This argument suggests that Morozov equated genocide with killing. Thus he argued that no group was destroyed through the transfer of children. ${ }^{50}$ The Belgian delegate, Kaeckenbeeck challenged this victim-specific stance given the delegates' rejection of the Syrian proposal. ${ }^{51}$

Other dissenting voices were concerned the alleged ambiguity of the clause. The Polish delegate, Manfred Lachs, distinguished between illegitimate transfers such as those carried out by the Germans during WWII, and legitimate transfers of children evacuated from the "theater of war" for their protection. ${ }^{52}$

\section{The UNGC and Beyond}

An ongoing research agenda is concerned with the opening up of the concept of genocide mainly with regard to two major issues: the type of groups protected by the UNGC and the proof of specific intent..$^{53}$ Restricting the protection granted under the UNGC to national, ethnical, racial or religious groups precludes the application of the FTC to otherwise strikingly similar cases of forcible transfers of children. The onus of specific intent is highly restraining because forcible transfers of children are often justified as stemming from benevolent motives, such as protection and civilization.

Beth van Schaak argues that the prohibition of genocide represents a paradigmatic peremptory norm (jus cogens), from which no derogation is permitted..$^{54}$ She asserts that the prohibition of genocide is expressed in a variety of sources..$^{55}$ Some of these are UN General Assembly Resolution 96(1) that "genocide is a crime under international law, which the civilized world condemns." Hence, the prohibition of genocide predates the UNGC. Furthermore, upon its review of the reservations to the UNGC made by the signatories, the International Court of Justice stated in 1951 that the prohibition of genocide is binding on states even in the absence of contractual obligation. ${ }^{57}$

The UN Secretary General's report to the Security Council on the establishment of the ICTY in 1993 lists the UNGC as comprising "part of conventional international humanitarian law which has beyond doubt become part of international customary law." ${ }^{58}$ Paragraph 45 of that report states: "The [Genocide] Convention is today considered part of international customary law as evidenced by the International Court of Justice in its Advisory Opinion on Reservations to the Convention on the Prevention and Punishment of Genocide, 1951."59

Judicial interpretations of international conventions aim at achieving a uniformity of the legal rules across tribunals, cases, and countries that are that are party to the conventions. There are at least three theories of interpretation, namely, originalism, progressivism and literalism. ${ }^{60}$ Both the ICTY and ICTR have adopted an originalist approach in adjudicating genocide by referring to the intentions of the drafters documented in the Travaux Préparatoires whenever they found the UNGC lacking detail. Addressing the evidentiary aspects of genocide based on the cases' specific circumstances, the tribunals have complemented the UNGC's underlying deontological ethic with consequential reasoning. ${ }^{61}$ While this originalist approach seems somewhat permissive, the two above mentioned issues are still wanting.

The FTC's victim-specificity allows for an inclusive view of protected groups with regards to children. The ICTR stated in Akayesu: "[I]t was necessary... to respect the intent of the drafters... which, according to the travaux preparatoires, was clearly to protect any stable and permanent group." 62 The Trial Chamber referred to the common criterion shared by the four groups protected by the UNGC, namely, that group membership would not seem readily challengeable by the members, who belong to it involuntarily, by birth, in a continuous and often irremediable manner. ${ }^{63}$ While the 
Akayesu Trial Chamber seems to have been somewhat inclined to expanding the boundaries of the UNGC with regard to the protected groups, subsequent case law has not followed this direction. ${ }^{64}$

In Rutaganda and Musema the ICTR Trial Chambers in each case noted that in the absence of a generally and internationally accepted precise definition of the types of protected groups, each group should be assessed in the light of a particular political, social, and cultural context. ${ }^{65}$ Both chambers held that membership in a group is subjective and based on the perpetrators' view of the victim as belonging to a group intended for destruction. ${ }^{66}$

Some of the perpetrators tried at the ICTR were charged with committing FTC. While the chambers did not acknowledge the cultural effects of the forcible transfers, the Akayesu Chamber was of "the opinion that, as in the case of measures intended to prevent births, the objective is not only to sanction a direct act of forcible physical transfer, but also to sanction acts of threats or trauma which would lead to the forcible transfer of children from one group to another." ${ }^{\prime 67}$

As mentioned earlier, the UNGC as a whole is essentially deontological as specific intent is a constitutive element of the crime. Specific intent requires that the perpetrator clearly seeks to produce the act charged. In the context of genocide it is "the intent to destroy, in whole or in part, a national, ethnical, racial or religious group." ${ }^{68}$ It "implies a condition of mind or purpose directed toward a particular objective ... that element must be alleged and proved." ${ }^{\prime 69}$

Intentions can be construed from action, inaction, and words. Indeed, in Akayesu, the ICTR agreed with the defense that intent might be difficult to establish. Yet it ruled that Akayesu's "actions, including circumstantial evidence, however may provide sufficient evidence of intent," and that "intent can be inferred either from words or deeds and may be demonstrated by a pattern of purposeful action." ${ }^{70}$ In Kayishema and Ruzindana the Trial Chamber held that "the mens rea must be formed prior to the commission of the genocidal acts." ${ }^{\prime 71}$ It further stated that "the individual acts themselves, however, do not require premeditation; the only consideration is that the act should be done in furtherance of the genocidal intent."72 Similarly, in Semanza, the Tribunal ruled: "A perpetrator's mens rea may be inferred from his actions."73 The ICTY also asserted, in the ruling of issuing indictments in the matters of Karadžić and Mladić that "[t]he intent which is peculiar to the crime of genocide need not be clearly expressed... [It] may be inferred from a certain number of facts such as the general political doctrine which gave rise to the acts." ${ }^{\prime 74}$

Tony Barta pursues a conception of genocide that embraces the relations of destruction. ${ }^{75}$ Barta argues that "the destruction of many peoples, genocidal outcomes, have been the result of complex and only obscurely discerned causes.." ${ }^{\prime 76}$ Hence, the definition of genocide should properly discard the special intent as its essential element. For Barta, actions imply relationships and bring about consequences, which people do not always foresee and expect. ${ }^{77}$ While Barta admits that genocide strictly cannot be a crime of unintended consequences, he actually introduces consequentialism into the notion of genocide. The ethical uniqueness of the FTC justifies such notion.

\section{The Forcible Transfer of Children as a System of Domination}

The victim-specific FTC is grounded in a dominant modernist discourse of children and childhood that developed in Europe from the eighteenth to the nineteenth century, and throughout most of the twentieth century. ${ }^{78}$ It is closely linked to the development of the modern nation state from the seventeenth to the nineteenth century. This discourse constructed childhood on a par with dependence. ${ }^{79}$ As the modern state defined itself through mutual military and economic competition and through colonization of remote parts of the world, the care of children, their upbringing and education became a major area of concern. ${ }^{80}$

Modernist conceptions of childhood and adulthood were constructed as dichotomous. Childhood was essentialized and framed as an age of futurity and dependency. ${ }^{81}$ Children were constructed as incomplete people with needs, and therefore assumed a passive role of a disciple, shaped and molded through punishments and reinforcements. ${ }^{82}$ Childhood was viewed as a journey towards adulthood, and children were valued for their potential contribution. ${ }^{83}$

Dependence was not only an objective matter of size and physical strength. It was, to a great extent, socially distributed. ${ }^{84}$ The state's disciplinary power, surveillance mechanisms, and "the gaze" were developed in the modern era and employed as mechanisms of control. ${ }^{85}$ In Bentham's notion of the Panopticon the state of constant visibility guarantees the smooth operating of power. ${ }^{86}$ 
Total institutions such as residential schools require this constant visibility enforcing obedience and conformity and for providing the children's alleged needs for protection.

Modern education of Indigenous children-consolidated under the labels of protection, civilization, and assimilation - was a part of the state's system of domination over Indigenous peoples. Foucault distinguishes between systems of domination and other forms of power relations. ${ }^{87}$ Whereas other forms of power relations allow some room for freedom, systems of domination exist when a certain class or group exercises power over others, controlling every aspect of life and leaving no room for freedom. ${ }^{88}$ Although these systems of domination represented themselves in the rhetoric of assimilation and integration, the education provided by these institutions was intended not only to destroy Indigenous cultures, but also to obtain a supply of menial work at a minimal public cost ${ }^{89}$ These systems of education sought to reproduce the submission of Indigenous people to the state that acted as an agent of exploitation and repression..$^{90}$

\section{Forcible Transfers of Indigenous Children: Canada, United States and Australia}

The programs for the removal of Indigenous children to Christian missions or schools developed during the nineteenth century in Canada, the U.S., and Australia were indeed part of the system of domination of the settlers that sought the extinction of Indigenous cultures and people as such. ${ }^{91}$ The children were forcibly removed from their families and communities and were violently forced to relinquish their group culture and adopt European culture. ${ }^{92}$

Almost every aspect and moment of the children's lives were structured and controlled to ensure the destruction of the children's Indigenous of identities..$^{93}$ All the same, the children's bodies and mental states were severely neglected and deprived. Students did not receive the same education as the general population. School curricula focused primarily on practical skills and preparation for menial vocations for boys and domestic services for girls. ${ }^{94}$ With forced labor, little time spent in class, and the long time devoted to intense work, most students had only reached grade five by the time they were $18 .{ }^{95}$ When the students had left these schools many were detached and traumatized. Many were discouraged from pursuing further education. The children received little or no medical care; many had contracted and died from severe diseases such as tuberculosis, trachoma, and other conditions that thrive in dense living conditions. Many children routinely suffered physical and sexual abuse. ${ }^{96}$ These programs continued into the 1990s in Canada. ${ }^{97}$

\section{Canada}

The Royal Proclamation of 1763 had defined the relationship between Indigenous and nonIndigenous people in North America. It was the result of the British military policy that recognized First Nations as its allies in its war against France in 1755-1830. ${ }^{98}$ Issued in the name of the King, the proclamation had set the rules that were to govern British dealings with Indigenous peopleespecially with regard to the Aboriginal title of land. ${ }^{99}$

A new set of policies based on a worldwide view of Britain's imperial and civilizing role was developed in 1837 by the British House of Commons Select Committee on Aborigines. ${ }^{100}$ The schooling of First Nations children became one of the objects of these new policies. Residential schools became central in the activity of the Missions. It was believed that the removal of children from their parents' influence would make them effective emissaries of Christian civilization. ${ }^{101}$

The Bagot Commission of 1842 recommended that the Indian Department should support the boarding schools operated by all religious denominations. While initially First Nations cooperated with and supported the residential schools, they never consented to their assimilationist policies. ${ }^{102}$

The British North America Act of 1867 granted the federal Parliament legislative authority over Indigenous peopled, and land reserved for them. ${ }^{103}$ This Act shaped educational systems, social policies and economic development plans designed to extinguish Indigenous rights and assimilate Indigenous people. ${ }^{104}$

In 1876, the first consolidated Indian Act reflected Canada's preoccupation with land management, First Nations membership and local government, and Canada's ultimate goal that consisted in the assimilation of its Indigenous population. ${ }^{105}$ The Indian Act was subject to numerous amendments since its legislation. Nevertheless it remains the principal tool for the exercise of power over "Status Indians," and governs many aspects of their lives. ${ }^{106}$ 
Between 1867 and the 1990s, the government of Canada, in collaboration with Christian church denominations, operated a system of residential schools. ${ }^{107}$ In 1887 Lawrence Vankoughnet, Deputy Superintendent-General of the Department of Indian Affairs wrote to Prime Minister John MacDonald: "Give me the children and you may have the parents ... [I]n working out that most difficult problem - the intellectual emancipation of the Indian, and its natural sequel, his elevation to a status equal to that of his white brother. This can only be done through education." ${ }^{108}$ About 150,000 Indigenous children were removed from their families and communities, sometimes forcibly by the mounted police, and placed in 130 residential schools between 1884 and $1996 .{ }^{109}$

The official objectives of this policy were to destroy Indigenous languages and cultures. The children were forbidden to speak their languages and were taught to reject their heritage, their families and, by extension, themselves. Parental visits were discouraged because they allegedly "demoralized the pupils" and high fences were to be erected as to prevent any contact of pupils and "obnoxious visitors." ${ }^{110}$ Many children suffered physical and mental deprivation, neglect, and physical and sexual abuse. Mortality rates due to malnutrition, abuse, and infectious disease such as tuberculosis soared in some schools to 35-60 percent. ${ }^{111}$

The safety of women and children became a major concern in Canada during the 1980s. ${ }^{112}$ Since 1990 there has been an increased focus by Indigenous people, governments and churches on the impact of residential schools and the survivors. In 1989 and 1990, prosecutions against former residential school staff began in British Columbia and the Yukon. ${ }^{113}$ Additional police investigations were followed by more claims. ${ }^{114}$ In 1990, Chief Phil Fontaine, then leader of the Association of Manitoba Chiefs, called for the churches involved to acknowledge the physical, emotional and sexual abuse endured in the schools. ${ }^{115} \mathrm{~A}$ year later, the Royal Commission on Aboriginal Peoples (RCAP) was established to investigate the social, economic and political conditions of the Aboriginal Peoples of Canada. The Report was published in 1996, yet "Gathering Strength - Canada's Aboriginal Action Plan" that was to address the RCAP's recommendation was not implemented. The report by the Law Commission of Canada established in 1997 issued recommendation for addressing the harm caused by the physical and sexual abuse of children in institutions funded, sponsored or operated by the government. ${ }^{116}$

In January 1998 Jane Stewart, Minister of Indian and Northern Affairs, issued a statement of reconciliation. ${ }^{117}$ Yet these measures could not contain the flood of legal cases filed against the Government of Canada and four Christian denominations, namely, the Anglican Church of Canada, Presbyterian, United Church of Canada, and Roman Catholic Church. ${ }^{118}$ Many of the litigants may have suffered from a unique form of post-traumatic stress disorder, known as "residential school syndrome." 119

By March 2004, all parties were dissatisfied with the measures. The Assembly of First Nations argued that the measures were insufficient, biased and too slow. In May 2005 the government signed the Political Agreement that undertook to negotiate a settlement package. This package was to include reparations for all former students of Indian residential schools, a Truth and Reconciliation Commission (TRC), community-based healing and commemoration. Because litigation proved problematic in addressing residential schools harms, an Alternative Dispute Resolution (ADR) process was to address the serious abuse suffered. ${ }^{120}$ In May 2006, the government, the Churches, and the Assembly of First Nations and other Aboriginal organizations reached agreement on a settlement to address the legacy of the Indian Residential School system (IRSS). ${ }^{121}$ The agreement included reparations, a truth commission, and commemoration. In June 2008, Prime Minister Stephen Harper offered an official statement of apology.

\section{The United States}

As in the Canadian case, the European-American Settlers' drive to civilize the Indians coincided with their ambition to acquire land. ${ }^{122}$ Subsequent to the War of 1812, Native Americans had lost their relevance as military allies, and were conceived of as an impediment to European expansion and control. ${ }^{123}$ The administration of Indian reservations was therefore entrusted to Christian denominations.

The Civilization Fund Act passed by the U.S. Congress on March 3, 1819 supported activities of benevolent societies in providing education for Native Americans. A Federal fund of $\$ 10,000$ was 
allocated to schools designed to educate Native Americans "in the ways of the white man."124 This legislation led to the establishment of boarding schools towards the end of the $19^{\text {th }}$ century.

In 1865 the government began to make contracts with several missionary societies for the maintenance of Indian schools for teaching agricultural and mechanical arts. This was the continuation of the plan for providing Federal aid to First Nations' education that was initiated 1818. ${ }^{125}$ Congress had allocated funds for the building of schools in the reservations to be operated by churches and missions. ${ }^{126}$

The boarding school system became formalized as part of President Ulysses S. Grant's Peace Policy of 1869 to $1870 .{ }^{127}$ The goal of Grant's Peace Policy was to turn over the administration of Indian reservations to Christian denominations. The first treaty agreement providing for any form of education was made December 2, 1794, with the Oneida, Tuscarora, and Stockbridge Indians, who had supported the United States during the Revolution. ${ }^{128}$ By the end of 1868, the Great Peace Commission possessed nine treaties that defined the various reservations that the tribes would inhabit. According to these treaties First Nations children would be educated "in the way of the white men," and English would be the language of instruction in order to facilitate the transition to "civilization." ${ }^{29}$ Congress funded the building of the schools, and entrusted the operation to churches and missionary societies. ${ }^{130}$

In her 1888 special report to Congress, ethnologist Alice C. Fletcher outlined the American concern over the education of Native American children and youth since $1775 .{ }^{131}$ Her chapter on education commences with the Mohegan's request from the Albany commissioners of the Indians, "to have teachers and instructors among them." ${ }^{132}$ The Commissioners promised to report this request to Congress.

Thomas J. Morgan, Commissioner of Indian Affairs from 1889-1893, reported the principles of the U.S. policy towards Indigenous peoples. First, " $t \mathrm{t}$ ] he reservation system belongs to a 'vanishing state of things' and must soon cease to exist."133 Native Americans, he said, "cannot escape [white civilization], and must either conform to it or be crushed by it."134

By the late 1870s policymakers realized that reservations' day schools were ineffective. Assimilation became increasingly aggressive. ${ }^{135}$ In 1891, Congress authorized the Commissioner of Indian Affairs to enforce the mandatory school attendance. ${ }^{136}$ Reservation boarding schools were built in order to isolate the children from their families and community. Soon after which off reservation schools were built to completely isolate the children.

The first off-reservation school, Carlisle, was founded in 1879 by Richard Pratt who thought that geographically distant off-reservation boarding schools would reinforce the separation of children from their parent until adulthood. ${ }^{137}$ In his words: "Transfer the savage-born infant to the surroundings of civilization, and he will grow to possess a civilized language and habit."138 The "outing system," namely, the placement of Native American children in white families was apparently successful. Morgan's 1889 Annual Report suggests that "[t]his system has in it the 'promise and the potency' of their complete emancipation."139

An 1894 article by Senator James H. Kyle from South Dakota, who chaired the U.S. Senate Committee on Education and Labor, reviews the "Indian problem." ${ }^{140}$ Kyle's article condemns the "heartless, grasping, conflicting policies."141 He argues that the purpose of the U.S. policy should be "to convert our Indian wards into intelligent American citizens." ${ }^{142}$ He further blames government officers, agencies, and employees for their "trickery and fraud" that disrupt the process of "civilization." Kyle writes that while many politicians shared these views, policy remained unchanged. ${ }^{143}$ While Kyle is allegedly sympathetic to Native Americans, he nevertheless believed in "the inevitable law of the subjection of the inferior to the superior race." 144

Like Kyle, Carl Schurz, a former Commissioner of Indian Affairs, and Secretary of the Interior, wrote that Native Americans face two stern alternatives, "extermination or civilization." 145 In his words, "a stubborn maintenance of the system of large Indian reservations must eventually result in the destruction of the red men, however faithfully the Government may endeavor to protect their rights. It is only a question of time." 146

The rationale for choosing aggressive assimilation over physical genocide was often economic. According to Schurz "it costs little less than a million of dollars to kill an Indian in war. It costs about one hundred and fifty dollars a year to educate one at Hampton or Carlisle." ${ }^{147}$ 
The findings of the 1928 Problem of Indian Administration (Meriam Report) unfold the poor conditions of Native Americans. ${ }^{148}$ The Report was commissioned by the Institute for Government Research, which later became the Brookings Institution. Its purpose was to gather information about the condition of Native Americans across the U.S. The Report was submitted to the Secretary of the Interior, Hubert Work, on February 21, 1928. The report criticized the Department of Interior's implementation of the General Allotment Act of 1877, and overall conditions on reservations and in Indian boarding schools. ${ }^{149}$

The Report found that the policy of removal as far as possible of Native American children should be revoked. It suggests that the modern point of view in education and social work highlights the value of upbringing children in their home environment. ${ }^{150}$ It recommended the decentralization of school curricula, providing a better diet, less over-crowding, less heavy productive work, more thorough physical examinations, and better correlation of remediable defects. ${ }^{151}$ The Report critically stated that "[f]rom the educational standpoint the young child does not belong in a boarding school."152 Francis Paul Prucha writes that the report strongly influenced policies in land allotment, health care and education and that the data it provided became an essential basis for reform. ${ }^{153}$

The 1930s witnessed a shift in educational philosophy. States assumed more control over First Nations education as more children enrolled in public schools. The Indian Commissioner from 1929-1934, Charles J. Rhoads, directed all boarding schools to phase out their first through third grade programs, to improve the quality of instruction achieve a better balance between vocational and academic education. ${ }^{154}$

Since the Meriam report there have been several other reports that unfolded the terrible conditions at the schools, the physical and sexual abuse, exploitation, the virtually non-existent or poor medical treatment, the high rates of deaths, and the effects of the forced separation of the children from their families. The Johnson O'Malley Act of 1934 was to subsidize the education of Native American children who did not live in reservation and were to be integrated into the public school system. ${ }^{155}$ Since then Congress enacted various laws dealing with the education of First Nations children. ${ }^{156}$

In 1969, a Senate Sub-committee on Indian Education issued a report entitled A National Tragedy - A National Challenge. The Report unfolded the terrible condition of the schools. ${ }^{157}$ It was followed by legislation such as the Indian Education Assistance Act of 1975, that allowed states to build schools on Indian land, and The Tribally Controlled Schools Act of 1988 allowed tribes to operate federally funded educational programs. ${ }^{158}$

Whereas critical reports of First Nations education were published over the years on the boarding schools system, changes were very slow and gradual. These reports, at least since the Meriam Report of 1928, render the good intentions argument in particular and temporal defense in general, highly dubious. ${ }^{159}$ These reports convey the rival views on First Nations education, and of the conditions and the consequences of these schools. The reality described in these reports and the failure to act in due course may strongly refute the good intentions argument in defense of the forcible transfer.

U.S. courts created the plenary power doctrine that gave the Federal government full and complete power over Indigenous people, immigrants, and colonized territories. ${ }^{160}$ This doctrine has been invoked several times in First Nations litigation "to justify the government's violation of both the constitution and international law." ${ }^{161}$ This doctrine would be used to argue that policies concerning the boarding schools were within the discretionary authority of the executive, over which the judiciary has no power.

U.S. Indian boarding schools litigation was mostly grounded in tort law, namely, that Government had breached the "bad men" clause. ${ }^{162}$ The "bad men" clause that was part of the peace-keeping treaties was in fact a commitment to protect Indians from white, or other "bad men" wanting to commit any wrong to the Indians or their property, and punish the perpetrators. ${ }^{163} \mathrm{In}$ 2004, Zephier and other six claimants submitted a class action suit in damages allegedly caused by sexual, physical, and mental abuse suffered between 1921-1924 at Indian schools managed by various church organizations and overseen by the Department of Indian Affairs. ${ }^{164}$ The plaintiffs argued the U.S. breached the "bad men" clause and its fiduciary duty as per the Sioux Treaty signed 
on April 29, 1868. ${ }^{165}$ Under the treaty, the Sioux agreed to move into a designated reservation, refrain from certain practices and to compel their children to attend boarding schools. The U.S. argued for and was granted a motion to dismiss alleging that the plaintiffs had failed to exhaust the available administrative remedies. Unlike Canada or Australia, the U.S. has not conducted a systematic comprehensive inquiry as the boarding schools and their impact, neither offered an official apology.

\section{Australia}

Tony Barta argues that Australian society is "founded on genocide."166 Aboriginal children have been forcibly separated from their families and communities since the very first days of the European occupation of Australia. ${ }^{167}$ As in the previous cases, the Australian practice of removing Aboriginal children from their family groups had an economic incentive. Aboriginal children were to play a role in filling the considerable labor void in various parts of Australia. ${ }^{168}$ The forcible removal of Aboriginal children also emanated from the British ontology regarding the threat posed by "problem populations." Forcible transfers became a common practice across colonial Australia by the late nineteenth century. ${ }^{169}$

The earliest child removal legislation in Australia was at state level, starting with the Victorian Aboriginal Protection Act 1869 (APA). ${ }^{170}$ Section 2(v) authorized the Aborigines Protection Board to enact regulations for "the care, custody and education of the children of Aborigines." ${ }^{171}$ One of the regulations made under the APA allowed for any Aboriginal child neglected by its parents or left unprotected, to be removed to a mission, an industrial or reform school, or a station. ${ }^{172}$ Another bylaw allowed the removal to an orphanage or any of the Board's branches of any orphaned halfcaste child, not otherwise required by the manager of a station. ${ }^{173}$

Using the Victoria Neglected and Criminal Children's Amendment Act of 1864, concerns about conditions in industrial schools led to an increase in children being boarded out to foster homes from the early 1870s. Foster parents were paid a weekly allowance by the state to cover a child's board. "Neglected" Aboriginal and non-Aboriginal children could be detained until the age of sixteen. Detained children could be boarded-out or apprenticed. The Regulations made under this Act in 1880 enabled reserve managers to order the removal of Indigenous children from their families.

The Queensland Aboriginal Protection and Restriction of the Sale of Opium Act 1897 that controlled every aspect of Aboriginal life authorized the government the right to exercise guardianship over all Aboriginal children in the colony of Queensland. ${ }^{174}$ Section 4 of the New South Wales Aboriginal Amending Act 1915 stated that "[ $\mathrm{t}]$ he Board may assume full control and custody" of any Aboriginal child for its best interest. ${ }^{175}$ These Queensland, Victorian and New South Wales statutes had formed the blueprint of legislation in the other states. ${ }^{176}$ By 1950 other Australian states adopted legislation that gave guardianship powers by Aboriginal Protectors over aborigines up to the age of 16 or 21 .

The 1913 South Australia Progress Report of the Royal Commission on Aborigines notes that "there are no reliable statistics" on the number of aborigines impacted by the laws. ${ }^{177}$ The Report also recommends separating the "full bloods" from half-caste natives. The latter were conceived of as better candidates for assimilation. ${ }^{178}$ Some officials suggested that "[t]hey should be taken away directly they are born. ${ }^{179}$ Governments and missionaries also targeted Indigenous children for removal from their families. Police or other officers of the state were authorized to locate infants and children of mixed marriages and remove them to state run institutions. ${ }^{180}$ The alleged motive was to "inculcate European values and work habits in children, who would then be employed in service to the colonial settlers." ${ }^{181}$ By the mid-1960s the process of removal of Aboriginal children to missions had slowed down. The last residential school was closed in either 1983 or $1984 .{ }^{182}$

Following demands of the Secretariat of the National Aboriginal and Islander Child Care and Aboriginal organizations demanded a national inquiry into the removal of Aboriginal children. ${ }^{183}$ On August 2, 1995, the Commonwealth of Australia's Attorney-General, Michael Lavarch commissioned the Australian Human Rights and Equal Opportunity Commission to conduct a national inquiry into the separation of Aboriginal children from their families.

The 1997 Bringing them Home report turns to the FTC in its inquiry over the separation of Torres Strait Islander children. It maintains that the predominant aim of the forcible transfers of 
Indigenous children was their assimilation into the dominant non-Indigenous society so that their unique cultural values and ethnic identities would disappear. ${ }^{184}$ It therefore concludes that the "[r] emoval of children with this objective in mind is genocidal because it aims to destroy the 'cultural unit' which the [Genocide] Convention is concerned to preserve." 185 This ground-breaking report incorporates many of the arguments and interpretations as to the prohibition of genocide as a jus cogens norm predating the UNGC. Hence, it considers the policy of forcible removal of Aboriginal children "genocidal" in breach of binding international law at least since the UN General Assembly approved resolution 96(1) of December 11, 1946. ${ }^{186}$ One of the recommendations of the Report was to establish a "National Compensation Fund," due to the procedural, evidential and financial difficulties involved in litigation. ${ }^{187}$

Two months after the Bringing them Home Report was submitted to the Australian Federal Parliament, in 1997 the High Court of Australia ruled in the matter of Kruger $v$ the Commonwealth. ${ }^{188}$ Kruger and a number of other Aboriginal claimants argued that the removal of Aboriginal children from their families and their detention authorized by the Northern Territory Aboriginals Ordinance of 1918 constituted cultural genocide. Cultural genocide, however, is not within the scope of the UNGC. The Government responded that the Ordinance was enacted in order to advance the welfare and interests of Aboriginals and half-caste Australians. ${ }^{189}$ The Court ruled that the Ordinance did not authorize the removal "with intent to destroy, in whole or in part the claimants' racial group." 190 The Court concluded that the Ordinance was a beneficial law and that it did not authorize act of genocide as defined in the UNGC. ${ }^{191}$ The Kruger decision in fact accepted the Government's temporal defense, namely, that "the constitutional validity of the Aboriginals Ordinance must be considered by reference to standards and perceptions prevailing at the time of its enactment or operation and not by reference to contemporary standards and perceptions."192

In 2008, former Prime Minister Kevin Rudd apologized to Aboriginal and Torres Strait Islander peoples for the laws and policies that "inflicted profound grief, suffering and loss."193 Rudd's apology acknowledged the abuses and policies of forced removal of Aboriginal and Torres Strait Islander children.

\section{Conclusion}

The forcible transfer cases in the U.S. and Australia outlined in the preceding sections, reveal a variety of legal and political technologies used by settler states for enhancing "the quality of the population and the strength of the nation." ${ }^{\prime 194}$ The vital role of the law emerges as the disillusioning module of this all-encompassing system of domination of Indigenous Peoples. Moreover, the law has been used to curb Indigenous claims ranging from various kinds of torts, breach of duty, and contractual obligation to cultural genocide.

Both scholars and survivors have attempted to apply the FTC to the residential and boarding school of Indigenous children. Yet, attempts to apply the UNGC to the Aboriginal residential schools have been legally ineffective due to doctrinal and procedural obstacles in both domestic and international law. The major doctrinal obstacles of FTC case law concern the need to establish specific intent in genocide claims.

The Canadian and Australian residential school litigation typically attempts to gain recognition of the residential schools as cultural genocide. Yet, because cultural genocide is not one of the acts enumerated by the UNGC, such claims have no legal merit. Moreover, the U.S. was not a signatory of the UNGC until November 25, 1988, and while Canada and Australia ratified it in 1952 and 1949 respectively, forcible transfers of Indigenous children to residential schools started about a century earlier.

While it be would be possible to use van Schaak's argument that the prohibition of genocide is a jus cogens norm and that during the relevant period, international customary law and norms prohibited the removal of children from their family based on their belonging to a particular group, the onus of specific intent still remains very difficult to prove.

Hence, in Kruger, Australia countered the Kruger's claims with temporal defense where the state typically argues that the policy of removal of Indigenous children was shaped by the prevailing during the establishment and operation of the schools and not by reference to contemporary standards. ${ }^{195}$ Indeed, assimilation was a dominant political and cultural doctrine at the time. 
Yet, evidence suggests that social science disciplines had already acknowledged the special links between children and their parents. Some officials involved in these forcible transfers believed that this practice was particularly cruel. ${ }^{196}$ By the early twentieth century the international community was well aware of the devastating effects of this practice.

All the same, Lemkin, like his contemporaries held complex, often contradictory views on colonialism and assimilation. He writes that "for better or for worse, Western culture has been and still is the master diffuser of the world." ${ }^{197}$ Lemkin distinguished assimilation by moderate coercion from cultural genocide. Regardless, he strongly opposed forcible transfers of children which he saw as kidnapping.

The piling evidence in official inquiry reports, TRC outcomes, and case law point to the pervasive, intergenerational devastating effects. In view of the FTC's ethical uniqueness, forcible transfers of children make a strong case for the widening the scope of UNGC. In particular, such changes should be evaluated based on ICC and ICTR and ICTY case law and the introduction of some consequentialist ethic into the UNGC. A pure deontological ethic that judges an act only by its intentions irrespective of the consequences renders such provisions almost inapplicable.

Residential school survivors in Canada have sought remedy through the use of tort law to argue for the loss of culture, breach of some contractual obligation. Canadian Indian residential schools case law suggests that the Government of Canada denies legal recognition of the loss of culture. ${ }^{198}$ Citing statutes of limitations, Canadian justice system allowed only "historical sexual assault," negligence, and breach of fiduciary duty as legally recognized harms. ${ }^{199}$

The plenary power doctrine gave the U.S. Federal government full and complete power over Indigenous people, immigrants, and colonized territories. Thus First Nations claims entered the domain of "political questions" over which the judiciary has no power. The statute of limitations and other procedural barriers were applied to Indigenous litigation.

Canada and Australia have granted recognition to the harms caused by residential schools but chose to settle the dispute outside the court. The Canadian ADR and Australian National Compensation Fund are indeed steps in the right direction, yet, they also convey the disillusionment with the law and the legal systems' historically molded by the contours of white settlers' hegemony.

\section{Endnotes}

1 Convention on the Prevention and Punishment of the Crime of Genocide, Public Law Resolution 260 (III) A, Office of the United Nations High Commissioner for Human Rights (1948).

2 William Schabas, Genocide in International Law: The Crimes of Crimes (Cambridge: Cambridge University Press, 2000), 175; Kurt Mundorff, “Other Peoples' Children: A Textual and Contextual Interpretation of the Genocide Convention, Article 2(e)," Harvard International Law Journal 50, 1 (2009): 63.

3 Schabas, Genocide in International Law: The Crimes of Crimes, 175.

4 See among other cases: The genocide of the Khoekho and San peoples of Southern Africa in the 18th century. Samuel Totten and Robert K. Hitchcock, Genocide of Indigenous Peoples, 8 (New Brunswick: Transaction Publishers, 2011); Keith David Watenpaugh, “The League of Nations' Rescue of Armenian Genocide Survivors and the Making of Modern Humanitarianism, 1920-1927," American Historical Review 115, 5 (2010): 1315-1339; Antonio Miguez Macho, "A Genealogy of Genocide in Francoist Spain," Genocide Studies and Prevention: An International Journal 8, 1 (2013): 21-32; Dorothy Legarreta, The Guernica Generation: Basque Refugee Children of the Spanish Civil War (Reno, Nev.: University of Nevada Press, 1984), 396; Kathlyn Gay, Leaving Cuba: From Operation Pedro Pan to Elian (Brookfield, Conn.: Twenty-First Century Books, 2000), 144; Yvonne M. Conde, Operation Pedro Pan: The Untold Exodus of 14,048 Cuban Children (New York: Routledge, 1999), 248; Victor Andres Triay, Fleeing Castro: Operation Pedro Pan and the Cuban Children's Program (Gainesville: University Press of Florida, 1998), 126. On Stalin's mass deportations on the Baltic states see Heinrihs Strod and Matthew Knott, "The File on Operation 'Priboi': A Reassessment of the Mass Deportations of 1949," Journal of Baltic Studies 33, 1 (2002): 1-31; On the Yemeni Children Affair see Ruth Amir, "Transitional Justice, Accountability and Memorialisation: The Yemeni Children Affair and the Indian Residential Schools," Israel Law Review 47 (2014): 3-26; Ruth Amir, Who is Afraid of Historical Redress? The Israeli Victim-Perpetrator Dichotomy (Brighton, MA: Academic Studies Press, 2012); On Ireland's Magdalene Laundries see James M. Smith, Ireland's Magdalen Laundries and the Nation's Architecture of Containment (Notre Dame, Ind.: University of Notre Dame Press, 2007).

5 Watenpaugh, “The League of Nations' Rescue of Armenian Genocide Survivors and the Making of Modern Humanitarianism 1920-1927," 1325. 
6 On the Indian Residential Schools Aboriginal experiences see for example David B. MacDonald and Graham Hudson, "The Genocide Question and Indian Residential Schools in Canada," Canadian Journal of Political Science 45, 2 (2012): 427-449; David B. MacDonald, "First Nations, Residential Schools, and the Americanization of the Holocaust: Rewriting Indigenous History in the United States and Canada," Canadian Journal of Political Science 40, 4 (2007): 995-1015; Andrew Woolford, "Ontological Destruction: Genocide and Canadian Aboriginal Peoples," Genocide Studies and Prevention: An International Journal 4, 1 (2009): 81-97.

7 Woolford, “Ontological Destruction: Genocide and Canadian Aboriginal Peoples," 81-97; MacDonald, "First Nations, Residential Schools, and the Americanization of the Holocaust: Rewriting Indigenous History in the United States and Canada," 995-1015 See also Roland Chrisjohn, T. Wasacase, L. Nussey, A. Smith, M. Legault, P. Loiselle, and M. Bourgeois, "Genocide and Indian Residential Schooling: The Past is Present," in Canada and International Humanitarian Law: Peacekeeping and War Crimes in the Modern Era, eds. R. D. Wiggers and A. L. Griffith (Halifax: Dalhousie University Press, 2002 ).

8 A tort is a civil wrong, other than a breach of contract, resulting in injury or harm in which the injured party seeks remedy. A tort allows the courts to award remedies such as a mandatory injunction, a prohibitory injunction or damages. Jules Coleman, "Theories of Tort Law," in Stanford Encyclopedia of Philosophy, ed. Edward N. Zalta (Stanford: The Metaphysics Research Lab Center for the Study of Language and Information, Stanford University, 2003), http://plato.stanford.edu/entries/tort-theories/ (accessed June 9, 2009).

9 The 1921 Convention for the Suppression of the Traffic in Women and Children, the 1924 Geneva Declaration of the Rights of the Child, and the 1926 prohibition of slavery.

101921 International Convention for the Suppression of the Traffic in Women and Children, as Amended by the 1947 Protocol, UN Treaty Collection, (November 12, 1947, 1947). The Slavery Convention http:// portal.unesco.org/culture/en/files/38440/12815475701Slavery Convention_\%281926\%29.pdf/ Slavery\%2BConvention\%2B\%281926\%29.pdf (accessed May 1, 2015)

11 Geneva Declaration of the Rights of the Child, Special Supplement 21, League of Nations Official Journal, (Sept. 26, 1924, 1924): 43. This declaration was proclaimed by the UN Secretary General in 1959. See Declaration of the Rights of the Child, 1386 (XIV), (December 10, 1959, 1959). The Declaration reiterated in the 1948 Universal Declaration of Human Rights, the Geneva Conventions and the 1977 Protocols, the 1998 Rome Statute and the UNCRC.

12 The League of Nations, Geneva Declaration of the Rights of the Child, 43. The same omission occurred in the 1959 UN Declaration of the Rights of the Child. United Nations, Declaration of the Rights of the Child. Who is a "child" and who an "adult" was to be determined to the law of the country. Nehemiah Robinson, The Genocide Convention; a Commentary (New York: Institute of Jewish Affairs, World Jewish Congress, 1960), 65.

13 The League of Nations, Geneva Declaration of the Rights of the Child, 43 See Article 5 in particular.

14 Tara Zahra, The Lost Children: Reconstructing Europe's Families After World War II (Cambridge, Mass.: Harvard University Press, 2011), 88-90. http://dx.doi.org/10.4159/harvard.9780674061378

15 Judith Lewis Herman, Trauma and Recovery, Rev ed. (New York: Basic Books, 1997), 12.; Onno van Der Hart, Paul Brown and Bessel A. Van Der Kolk, "Pierre Janet's Treatment of Post-Traumatic Stress," Journal of Traumatic Stress 2, 4 (1989): 5-6; Zahra, The Lost Children: Reconstructing Europe's Families after World War II, 10-11.

16 Diane Marie Amann, "Children and the First Verdict of the International Criminal Court," Washington University Global Studies Law Review 12 (2013): 415; Nuremberg International Military Tribunal, "Indictment," in Trial of the Major War Criminals before the International Military Tribunal under Control Council Law no. 10. Vol. 1 (Washington D.C.: Government Printing Office, 1947), 27-95; the atrocities towards children are noted in page 50 .

17 International Military Tribunal, Trials of War Criminals before the Nuernberg Military Tribunals Under Control Council Law no. 10, Vol. 5, (Washington D.C.: United States Government Printing Office, 1949), 626.

18 International Military Tribunal, Trials of War Criminals before the Nuernberg Military Tribunals Under Control Council Law no. 10. Vol. 5, 30-31.

19 The United Nations War Crimes Commission, Law Reports of Trials of War Criminals, Vol. 7 (London: The United Nations Crimes Commission and His Majesty's Stationary Office, 1948).; The United Nations War Crimes Commission, Law Reports of Trials of War Criminals, Vol. 13 (London: The United Nations Crimes Commission and His Majesty's Stationary Office,1949).

20 The Sixth Committee was opposed to granting the same protection to adults. See Sixth Committee of the UN General Assembly, “UN Document A/C.6/238, Third Session Dated October 19, 1948," in The Genocide Convention: The Travaux Préparatoires, eds. Hirad Abtahi and Philippa Webb, Vol. 2 (Leiden; Boston: Martinus Nijhoff Publishers, 2008), 1990. Forced transfers constitute crimes against humanity according to the Rome Statute (Article 7d). The Rome Statute: https://www.icrc.org/ihl/WebART/585-07?OpenDocument (accessed on February 13, 2015) 
21 Samuel Scheffler, "Agent-Centred Restrictions, Rationality, and the Virtues," in Consequentialism and its Critics, ed. Samuel Scheffler (Oxford: Oxford University Press, 1988), 243.

22 Steven Sverdlik, Motive and Rightness (Oxford; New York: Oxford University Press, 2011). http://dx.doi. org/10.1093/acprof:oso/9780199594948.001.0001

23 Michael S. Moore, "Patrolling the Borders of Consequentialist Justifications: The Scope of Agent Relative Restrictions," Law and Philosophy 27, 1 (2007): 38-39. See also Sverdlik, "Motive and Rightness," 8.

24 Fred Feldman, "Adjusting Utility for Justice: A Consequentialism Reply to the Objection from Justice," Philosophy and Phenomenological Research 35, 3 (1995): 567-568. http://dx.doi.org/10.2307/2108439

25 John Rawls, A Theory of Justice (Oxford: Clarendon Press, 1972), 27; Samuel Scheffler, "Introduction," in Consequentialism and its Critics, ed. Samuel Scheffler (Oxford: Oxford University Press, 1988), 2-5.

26 Feldman, Adjusting Utility for Justice: A Consequentialism Reply to the Objection from Justice, 568; Samuel Scheffler, Consequentialism and its Critics (Oxford; New York: Oxford University Press, 1988); Julia Driver, Consequentialism (Abingdon, Oxon; New York: Routledge, 2012).

27 On deontological theories see Samuel Scheffler, "Introduction," in Consequentialism and its Critics, ed. Samuel Scheffler (Oxford: Oxford University Press, 1988), 9-12.

28 F. M. Kamm, Intricate Ethics: Rights, Responsibilities, and Permissible Harm (Oxford: Oxford University Press, 2007), 27. http://dx.doi.org/10.1093/acprof:oso/9780195189698.001.0001

29 Ibid., 28-29.

30 George W. Harris, Agent-Centered Morality: An Aristotelian Alternative to Kantian Internalism (Berkeley: University of California Press, 1999), 2-6.

31 Sen argues that all societies and cultures comprise diverse elements. Elements within Western cultures, philosophies, and societies that are allegedly supportive of universal human rights have developed ideas and practices such as slavery, racism, fascism and sexism. In particular, his work on economics and human rights is of particular relevance in the context of the FTC. See Amartya K. Sen, "Legal Rights and Moral Rights: Old Questions and New Problems," Ratio Juris 9, 2 (1996): 153-167; Amartya K. Sen, "Elements of a Theory of Human Rights', Philosophy and Public Affairs," Philosophy and Public Affairs 32, 4 (2004): 315-356.

32 Raphael Lemkin, “Orphans of Living Parents: A Comparative Legal and Sociological View," Law and Contemporary Problems 10 (1944): 834-854. http://dx.doi.org/10.2307/1189994

33 Raphael Lemkin, “The Treatment of Young Offenders in Continental Europe," Law and Contemporary Problems 9 (Fall 1942, 1942): 748-759.

34 International Military Tribunal, Trials of War Criminals before the Nuernberg Military Tribunals Under Control Council Law no. 10, Vol. 4 (Washington D.C.: Government Printer, 1949), 674.

35 Raphael Lemkin and Donna-Lee Frieze, Totally Unofficial: The Autobiography of Raphael Lemkin, 2013), 168.

36 The United Nations Secretary General, "E/447 Draft Convention for the Prevention and Punishment of Genocide, Dated June 26, 1947," in The Genocide Convention: The Travaux Préparatoires, Vol. 1, 215.

37 Ibid., 235

38 The United Nations, The Economic and Social Council, “UN Doc E/AC.25/12 Ad Hoc Committee on Genocide (5 April-10 may 1948) Draft Convention on Prevention and Punishment of the Crime of Genocide (Drawn Up by the Committee)," in The Genocide Convention: The Travaux Préparatoires, Vol. 1, 1161-1166.

39 Sixth Committee of the UN General Assembly, UN DOC A/C.6/SR.81, Eighty-First Meeting Dated October 22, $1948,1478-1479$

40 Sixth Committee of the UN General Assembly, UN DOC A/C.6/SR.82, Eighty-Second Meeting Dated October 23, 1948, 1492-1499.

41 Raphael Lemkin and Donna-Lee Frieze, Totally Unofficial: The Autobiography of Raphael Lemkin, 168-169.

42 Sixth Committee of the UN General Assembly, UN DOC A/C.6/SR.82, 1496.

43 Ibid., 1496.

44 Ibid., 1492-1493.

45 Sixth Committee of the UN General Assembly, UN DOC A/C.6/SR.82, 1492.

46 Sixth Committee of the UN General Assembly, UN DOC A/C.6/SR.82, 1494.

47 Sixth Committee of the UN General Assembly, UN Document A/C.6/238, Third Session Dated October 19, 1948, 1990.

48 Ibid., 1493.

49 Ibid., 1493. 
50 Ibid., 1497.

51 Ibid., 1495.

52 Ibid., 1495.

53 See Beth Van Schaak, "The Crime of Political Genocide: Repairing the Genocide Convention's Blind Spot," Yale Law Journal 106 (1997): 2259-2291; Woolford, "Ontological Destruction: Genocide and Canadian Aboriginal Peoples," 81-97; Frank Chalk, "Genocide in the 20th Century: Definitions of Genocide and their Implications for Prediction and Prevention," Holocaust and Genocide Studies 4, 2 (1989): 152. On specific intent see: William A, Schabas, "The Jelisic Case and the Mens Rea of the Crime of Genocide," Leiden Journal of International Law 14, 1 (2001): 125-139.Contra about the type of groups see D'Amato, On Genocide, in International Law Across the Spectrum of Conflict: Essays in Honour of Professor L.C. Green on the Occasion of His Eightieth Birthday, Naval War College International Law Studies "Blue Book," 119-130, 123, 129

54 Van Schaak, “The Crime of Political Genocide: Repairing the Genocide Convention's Blind Spot," 2261.

55 Ibid., 2286

56 The United Nations General Assembly, "Resolution 96(1), 11 December 1946, the Crime of Genocide, 55 Plenary Meeting Dated December 11, 1946," in The Travaux Préparatoires of Multilateral Treaties, vol. 1, ed. Jean Allain (Leiden; Boston: Martinus Nijhoff Publishers, 2008), 34.

57 Reservations to the Convention on the Prevention and Punishment of the Crime of Genocide: Advisory Opinion, 28 May 1951, in ICJ Reports (1951), 23.

58 Report of the Secretary General pursuant to paragraph 2 of Security Council Resolution 808 (1993), UN Doc. S/25704, 2 May 1993, para. 35

59 Ibid., para. 45.

60 Greg Craven, “Heresy Or Orthodoxy: Were the Founders Progressivists?" Federal Law Review 31, 1 (2003): 87-129.There are at least three general approaches to constitutional interpretation, namely, originalism, progressivism and literalism. Originalism is a theory of constitutional interpretation. It posits that the fundamental task of the Courts is usually regarded as being to interpret the constitution by referring to the intentions of those who framed it. Progressivism posits that rather than searching for the historical intention of the Founders the court should construe the Constitution so as to bring it into accord with modern needs and exigencies. Literalism is the strict adherence to the letter of the law. 'Originalist interpretation' in the context of this article refers to the interpretation of the prohibition on genocide as the drafters of the UNGC intended it.

61 The Prosecutor v. Jean-Paul Akayesu, 2 September 1998, ICTR-96-4-T; The Prosecutor v. Clement Kayishema and Obed Ruzindana, 21 May 1999, ICTR-95-1-T; The Prosecutor v. Radoslav Brdjanin, 1 September, 2004, IT-9936-T, 704; The Prosecutor v. Goran Jelisić, 14 December 1999, IT-95-10-T, 47; The Prosecutor v. Radislav Krstić, 19 April 2004, IT-98-33-A, para.34; The Prosecutor v. Milomir Stakić, 31 July 2003, IT-97-24-T, para.526.

62 Akayesu, September 2, 1998, para. 511 (emphasis added). See also The Prosecutor $v$ Alfred Musema, January 27, 2000, ICTR 96-13-A, para.161.

63 Akayesu, para. 511. See also Musema, para. 161.

64 I thank an anonymous referee for this point.

65 The Prosecutor v. Georges Anderson Nderubumwe Rutaganda, December 6, 1999, ICTR 96-3-T, para 56; Musema, para. 161.

66 Musema, para. 160-163; Rutaganda, para. 57-58

67 Akayesu, para. 509; see also Musema, para. 159; Rutaganda, para. 54.

68 United Nations, Convention on the Prevention and Punishment of the Crime of Genocide, Article II See also Raphael Lemkin, "On the Need for a Genocide Convention" (Unpublished, Raphael Lemkin Collection, Box 7, Folder 2, American Jewish Historical Society, Boston, MA and New York, NY, Undated).; Jason J. Campbell, On the Nature of Genocidal Intent (Lanham: Lexington Books, 2013).

69 Lemkin, On the Need for a Genocide Convention, 22.

70 Akayesu, September 2, 1998, paras. 523-534.

71 Kayishema and Obed Ruzindana, para. 91.

72 Ibid., 91.

73 The Prosecutor v. Semanza, May 15, 2003, ICTR-97-20, para. 313.

74 See the transcript of the ruling issuing indictments against Karadžić \& Mladić. The Prosecutor v. Radovan Karadžić \& Ratko Mladić, July 11, 1996, IT-95-5-R61, IT 95-18-R61, para 94. 
75 Barta, Relations of Genocide: Land and Lives in the Colonization of Australia, 238

76 Ibid., 238

77 Ibid., 238

78 Jean Jacques Rousseau (1712-1778), Étienne Bonnot de Condillac (1715-1780), and Gottfried von Herder (1744-1803) explored philosophical aspects of childhood. Dietrich Tiedemann's (1748-1803) study is the first known empirical work on child development. It was first published in 1787 in German. The book was published in English in 1890. Dietrich Tiedemann and Bernard Perez, Tiedemann's Record of Infant-Life, 13 (Syracuse, N.Y.: C.W. Bardeen, 1890), 46.

79 John Caldwell Holt, Escape from Childhood: The Needs and Rights of Children (Harmondsworth: Penguin, 1975), 5.

80 Nick Lee, Childhood and Society: Growing Up in an Age of Uncertainty (Buckingham: Open University, 2001), 22-23.

81 Ibid., 24-30

82 William A. Corsaro, The Sociology of Childhood, 3rd ed. (Los Angeles: Sage/Pine Forge Press, 2011), 10.

83 Allison James, Key Concepts in Childhood Studies, ed. Adrian L. James, 2nd ed. (Los Angeles, Calif.; London: Sage, 2012), 24.

84 Lee, Childhood and Society: Growing Up in an Age of Uncertainty, 24; Jens Qvortrup, Studies in Modern Childhood: Society, Agency, Culture (Houndmills, Basingstoke, Hampshire; New York: Palgrave Macmillan, 2005); Corsaro, The Sociology of Childhood

85 Michel Foucault, Discipline and Punish: The Birth of the Prison, 2nd ed. (New York: Vintage Books, 1977), 195-228.

86 Alan Sheridan, Michel Foucault: The Will to Truth (London ; New York: Tavistock, 1980), 153..

87 Michel Foucault and Sylvère Lotringer, Foucault Live: (Interviews, 1966-84) (New York: Semiotexte, 1989), 442.

88 Ibid.

89 Jacques Donzelot and Robert Hurley, The Policing of Families, John Hopkins (Baltimore: Johns Hopkins University Press, 1997), 16.

90 Louis Althusser, Lenin and Philosophy and Other Essays (London: New Left Books, 1977), 132.

91 David Wallace Adams, Education for Extinction: American Indians and the Boarding School Experience, 18751928 (Lawrence, Kan.: University Press of Kansas, 1995), 335.

92 Jennifer Llewelyn, "Dealing with the Legacy of Native Residential School Abuse in Canada: Litigation, ADR and Restorative Justice," University of Toronto Law Journal 52 (2002): 255.

93 Senate Special Subcommittee on Indian Education, Committee on Labor \& Public Welfare, Indian Education: A National Tragedy - A National Challenge, S. REP. NO. 91-501 (1969), 64.

94 See Andrea Smith, "Soul Wound: The Legacy of Native American Schools," Amnesty International Magazine (March 26, 2007) available online at http://www.amnestyusa.org/node/87342 (accessed May 1, 2015).

95 Ibid.

96 Andrea Anne Curcio, "Civil Claims for Uncivilized Acts: Filing Suit against the Government for American Indian Boarding School Abuses," Hastings Race and Poverty Law Journal 4, (2006): 45.

97 As of the mid-1980s the Federal Government of Canada no longer had control over residential schools. However, the last residential school closed in Regina Saskatchewan in 1996.

98 Andrew Armitage, Comparing the Policy of Aboriginal Assimilation: Australia, Canada, and New Zealand (Vancouver: UBC Press, 1995), 73-74.

99 Wendy Moss and Elaine Gardner-O'toole, Aboriginal People: History of Discriminatory Laws (Ottawa: Library of Parliament Research Branch, 1991), 12; Richard H Bartlett, "The Indian Act of Canada," Buffalo Law Review 27 (1977): 581.

100 Armitage, Comparing the Policy of Aboriginal Assimilation: Australia, Canada, and New Zealand, 74-75.

101 John Webster Grant, Moon of Wintertime: Missionaries and the Indians of Canada in Encounter since 1534 (Toronto; Buffalo: University of Toronto Press, 1984), 86-87.

102 Donald Lee Fixico, Treaties with American Indians: An Encyclopedia of Rights, Conflicts, and Sovereignty (Santa Barbara, CA: ABC-Clio, 2008), 745-746.

103 Constitution Act, 30 \& 31, C. 3 sess., (1867): Victoria, c 3 (U.K.), R.S.C. 1985, App 2, No 11. 
104 Canada, Report of the Royal Commission on Aboriginal Peoples, 1: Looking Forward, Looking Back (Ottawa: The Government of Canada, 1996).

105 Bartlett, 581-582.

106 Indian Act R.S.C. 1985, c I-5.

107 The first missionary-operated school in Canada was established near Quebec City between 1620 and 1629 , more than 200 years before the first Indian residential school was opened in Brantford, Ontario in 1831. The Brantford school would remain one of the longest lasting Indian Residential Schools was closed in 1969.

108 Quoted in ibid, 58.

109 John Milloy, Indian Act Colonialism: A Century of Dishonour, 1869-1969 (National Centre for First Nations Governance, 2008). See Chapter 4 in particular, 51-76. The 2007 Indian Residential Schools Settlement Agreement included 130 schools. Seven schools were added through Article 12 by Canada and the two schools which were added by the courts, bringing the total number of recognized schools to 139 . See the Aboriginal Affairs and Northern Development website, available at https://www.aadnc-aandc.gc.ca/ eng/1100100015606/1100100015611 (accessed on April 29, 2015) Dominion of Canada, The Department of Indian Affairs, Annual Report of the Department of Indian Affairs for the Year Ended 31st December 1884 (Ottawa: MacLean, Roger \& Co., 1885).

110 Ibid., 77.

111 Megan Sproule-Jones, “Crusading for the Forgotten: Dr Peter Bryce, Public Health, and Prairie Native Residential Schools" Canadian Bulletin of Medical History 13, (1996): 199-224, 204.

112 John S. Milloy, A National Crime: The Canadian Government and the Residential School System 1789-1986. (Winnipeg: University of Manitoba Press, 1999), 298.

113 Courtney Jung, "Canada and the Legacy of the Indian Residential Schools: Transitional Justice for Indigenous Peoples in a Non-Transitional Society," in Identities in Transition: Challenges for Transitional Justice in Divided Societies, ed. Paige Arthur (New York: Cambridge University Press, 2011), 7.

114 Canada, Report of the Royal Commission on Aboriginal Peoples, Vol.1: Looking Forward, Looking Back, Part 1 Chapter 6

115 Ibid., 1, 377-378.

116 Law Commission of Canada, Restoring Dignity Responding to Child Abuse in Canadian Institutions (Ottawa: Minister of Public Works and Government Services, 2000).

117 John DeMont and Bruce Wallace, “Ottawa Apologizes to Natives," The Canadian Encyclopedia, 19 January 1998, http://www.thecanadianencyclopedia.ca/en/article/ottawa-apologizes-to-natives/ (accessed May 1, 2015).

118 Llewelyn, "Dealing with the Legacy of Native Residential School Abuse in Canada: Litigation, ADR and Restorative Justice," 253-300.The Catholic Oblates of Marry Immaculate is responsible for 60\% of the schools across Canada. See Blackwater v Plint 2001 BCSC 997 British Colombia Superior Court; Baxter v Canada, Charles Baxter Sr and Elijah Baxter et al v Attorney General of Canada et al, Ontario Superior Court of Justice, court file no 00-CV-192059CV, December 15, 2006; Fontaine v. Canada (Attorney General), 2014 Ontario Superior Court of Justice, Court file no 00-CV-129059, January 14, 2014. See also Bruce Feldthusen, "Civil Liability for Sexual Assault in Aboriginal Residential Schools: The Baker Did It," Canadian Journal of Law and Society 22, 1 (2007): 61-91; Zoe Oxaal, "'Removing That Which was Indian from the Plaintiff': Tort Recovery for Loss of Culture and Language in Residential School Litigation," Saskatchewan Law Review 68 (2005): 367-404.

119 Charles R. Brasfield, “Residential School Syndrome,” British Columbia Medical Journal 43, 2 (2001): 78-81.; Aaron Denham, "Rethinking Historical Trauma," Transcult Psychiatry 45, 3 (2008): 391-414.

120 Llewelyn, "Dealing with the Legacy of Native Residential School Abuse in Canada: Litigation, ADR and Restorative Justice," 253-300.

121 Available online at http://www.residentialschoolsettlement.ca/english index.html (accessed May 1, 2015).

122 David Wallace Adams, Education for Extinction: American Indians and the Boarding School Experience, 18751928,6 .

123 J. R. Miller, Skyscrapers Hide the Heavens: A History of Indian-White Relations in Canada, 3rd ed. (Toronto ; Buffalo: University of Toronto Press, 2000), 135.

124 United States. Alice C. Fletcher and United States Office of Education. Special Report, 1888, Indian Education and Civilization (Washington: Govt. print. off., 1888), 163.

125 Fritz, "The Making of Grant's 'Peace Policy,"' 415 
126 David Wallace Adams, Education for Extinction: American Indians and the Boarding School Experience, 18751928 (Lawrence, Kan.: University Press of Kansas, 1995), 57-58.

127 Fritz, “The Making of Grant's 'Peace Policy,"' 411-432

128 Ibid., 162

129 Francis Paul Prucha, Documents of United States Indian Policy, 3rd ed. (Lincoln: University of Nebraska Press, 2000), 277, 280-281. See also J. D. C. Atkins, "Annual Report of the Commissioner of Indian Affairs, September 21, 1887," in Documents of United States Indian Policy, ed. Francis Paul Prucha, 3rd ed. (Lincoln: University of Nebraska Press, 2000), 173-175.

130 Fritz, “The Making of Grant's ‘Peace Policy,"' 411-432

131 United States. Fletcher and United States Office of Education. Indian Education and Civilization, 161-197

132 Ibid., 161

133 Thomas J. Morgan, “Annual Report of the Commissioner of Indian Affairs, October 1, 1889," in Documents of United States Indian Policy, ed. Francis Paul Prucha, 3rd ed. (Lincoln: University of Nebraska Press, 2000), 175-176.

134 Ibid., 176

135 Adams, Education for Extinction: American Indians and the Boarding School Experience, 1875-1928, 28-30

136 Act of March 3, 1891, ch. 543, 26 Stat. 989, 1014.

137 David Wallace Adams, Education for Extinction: American Indians and the Boarding School Experience, 18751928, 57-58.

138 Cited in Ibid., 52.

139 Morgan, Annual Report of the Commissioner of Indian Affairs, October 1, 1889, 178

140 James H. Kyle, "How Shall the Indians be Educated?" The North American Review 159, 455 (1894): 434-447.

141 James H. Kyle, “How Shall the Indians be Educated?," 435.

142 Ibid., 435

143 Ibid., 435

144 Ibid., 435

145 Carl Schurz, "Present Aspects of the Indian Problem," The North American Review 133, 296 (1881): 7.

146 Ibid., 6.

147 Ibid., 17.

148 Brookings Institution. Institute for Government Research and Lewis Meriam, The Problem of Indian Administration (New York: Johnson Reprint Corp., 1971), 10-51.

149 The General Allotment Act was adopted by Congress in 1887. The act was "to provide for the allotment of lands in severalty to Indians on the various reservations, and to extend the protection of the laws of the United States and the Territories over the Indians, and for other purposes to stimulate assimilation of Indians into mainstream American society." http://digital.library.okstate.edu/kappler/vol1/html files/ ses0033.html (accessed on April 22, 2015)

150 Ibid., 32.

151 Ibid., 33.

152 Ibid., 34.

153 Francis Paul Prucha, The Great Father: The United States Government and the American Indians, (Lincoln: University of Nebraska Press, 1986), 312-316.

154 Records of the Bureau of Indian Affairs Central Classified Files, 1907-1939 Series D: Education Part 2: Correspondence and Reports on Reservation Day and Boarding Schools Section B: Pine Ridge through Zuni, available online at http://cisupa.proquest.com/ksc assets/catalog/102688.pdf (accessed May 1, 2015)

155 Act of April 16, 1934, Pub. L. No. 73-167, 48 Stat. 596 (codified as amended at 25 U.S.C. §§ 452-457).

156 For example, the Impact Aid legislation granted federal subsidies to state operated public schools for the education of children "connected" with federal lands exempt from taxation, including Indian reservations. Pub. L. 81-874, c. 1124, 64 Stat. 1100 (1950), codified as amended at 20 U.S.C. §§7701- 7714; See the Elementary and Secondary Education Act of 196520 U.S.C. §§ 2701-2713 (2004).

157 Senate Special Subcommittee on Indian Education, Committee on Labor \& Public Welfare, Indian Education: A National Tragedy - A National Challenge, S. REP. NO. 91-501 (1969). 
15825 U.S.C. 2511.

159 In order to exonerate the state as an historical actor based on temporal defense, one ought to assess the political, social climate and moral norms. Were they monolithic or was there a rival doctrine? See Eric L. Muller, "Fixing a Hole: How the Criminal Law can Bolster Reparations Theory," Boston College Law Review 47, no. 4 (2006): 661-662.

160 Andrea Anne Curcio, “Civil Claims for Uncivilized Acts: Filing Suit against the Government for American Indian Boarding School Abuses" Hastings Race and Poverty Law Journal 4, (2006): 45-129, at 81. See Stephen L. Pevar, The Rights of Indians and Tribes, (Oxford; New York: Oxford University Press, 2012), 82-84.

161 Curcio, “Civil Claims for Uncivilized Acts: Filing Suit against the Government for American Indian Boarding School Abuses," 81.

162 This was made possible under the Tucker Act. 28 U.S.C. § 1491. The Tucker act gives the Federal Court of Claims jurisdiction over any claim stemming from an expressed or implied contract. See Curcio, 79-80.

163 Ibid., 45. See Begay v. United States, 224 Ct. CI. 712 (1980). The Court allowed Navajo children harmed by a teacher to file a claim under the "bad men" provision.

164 Zephier, et al. v. United States of America, U.S. Court of Federal Claim, No 03-768L, October 29, 2004.

165 Treaty between the United States of America and Different Tribes of Sioux Indians, U.S.-Sioux, art. 1, Apr. 29, 1868, 15 Stat. 635

166 Barta, Relations of Genocide: Land and Lives in the Colonization of Australia, 238 Contra see Henry Reynolds, An Indelible Stain? The Question of Genocide in Australia's History (Ringwood, Vic.; Harmondsworth: Viking, 2001).

167 Australia. Human Rights and Equal Opportunity Commission., Bringing them Home: Report of the National Inquiry into the Separation of Aboriginal and Torres Strait Islander Children from their Families (Sydney: Human Rights and Equal Opportunity Commission, 1997), 2.

168 Shirleene Robinson \& Jessica Paten, "The question of genocide and Indigenous child removal: The colonial Australian context," Journal of Genocide Research 10, 4 (2008): 501-518. http://dx.doi. org/10.1080/14623520802447818

169 Ibid., 502.

170 Aboriginal Protection Act 1869 (Vic), 2. Available online at http://www.foundingdocs.gov.au/resources/ transcripts/vic7i doc 1869.pdf (accessed March 15, 2015).

171 Ibid.

172 Aboriginal reserves and stations were portions of land assigned by the New South Wales Department of Lands, from the 1860s until about 1914 for the use of Aboriginal people. An Aboriginal station was a managed reserve. A resident teacher-manager appointed by the Aboriginal Protection Board. The stations usually contained a school and a clinic, and served as a depot for the allocation of blankets, rations and supplies to Aboriginal people.

173 Aborigines Act (Vic) 1890, Item 2 Regulations 1871-1937, CRS B313 NAA VIC available online at http://guides.slv.vic.gov.au/content.php?pid=149820\&sid=1328875 (accessed March 15, 2015)

174 Aboriginal Protection and Restriction of the Sale of Opium Act (QLD). Available online at http://ozcase.library. qut.edu.au/qhlc/documents/qr abor Aboriginals 189761 Vic No 17.pdf (accessed March 15, 2015)

175 Aborigines Protection Amending Act (NSW), Act No. 2, 1915, 122 (Assented to, 15th February 15, 1915) Available online at http://www5.austlii.edu.au/au/legis/nsw/num act/apaa1915n2321.pdf (Accessed March 15, 2015) The parents of a removed child were granted the right to appeal before a court of law.

176 In Tasmania, however, general welfare legislation was used for the removal of Aboriginal children.

177 Ibid., v.

178 Ibid., xvii.

179 South Australia, Progress Report of the Royal Commission on the Aborigines, 121, 125.

180 Robert van Krieken, “The Barbarism of Civilization: Cultural Genocide and the 'Stolen Generations', " British Journal of Sociology 50, 2 (1999): 297-315.; Peter Read, The Stolen Generations: The Removal of Aboriginal Children in New South Wales 1883 to 1969 (Surry Hills, NSW: New South Wales Department of Aboriginal Affairs, 2006).; Quentin Beresford and Paul Omaji, Our State of Mind: Racial Planning and the Stolen Generations (Fremantle, W.A.: Fremantle Arts Centre Press, 1998), 295; Martin Crotty and David Andrew Roberts, The Great Mistakes of Australian History (Sydney, NSW: University of New South Wales Press, 2006), 244.

181 Quoted in Jan Mason, Child Welfare Policy: Critical Australian Perspectives (Sydney, NSW: Hale \& Iremonger, 1993), 31. 
182 Antonio Buti, "The Removal of Aboriginal Children: Canada and Australia Compared," University of Western Sydney Law Review 2 (2002).

183 Ibid

184 Australian Human Rights and Equal Opportunity Commission, Bringing them Home: Report of the National Inquiry into the Separation of Aboriginal and Torres Strait Islander Children from their Families, (Sydney: Human Rights and Equal Opportunity Commission, 1997), 237.

185 Ibid., 237.

186 Ibid., 239.

187 Ibid., 305.

188 Kruger $v$ the Commonwealth [1997] 146 ALR 126 (July 31, 1997).

189 The same position was reiterated in Cubillo v the Commonwealth (2000) FCA 1084, (August 11, 2000), para. 1560.

190 Kruger $v$ the Commonwealth, para. 51; See analysis at Sarah Joseph, "Case Commentary: Kruger v Commonwealth: Constitutional Rights and the Stolen Generations," Monash University Law Review 24, 2 (1998).available online at http://www.austlii.edu.au/au/journals/MonashULawRw/1998/18.pdf (accessed April 28, 2015)

191 Kruger $v$ the Commonwealth, para. 66.

192 Kruger $v$ the Commonwealth, para. 29 (e) of the Commonwealth's Amended Defense. On temporal defense see Eric L. Muller, "Fixing a Hole: How the Criminal Law can Bolster Reparations Theory," 661-662. While Gray J in Trevorrow v South Australia has also accepted that the primary purpose of the legislation in question was to support and protect Aboriginal children, he held that it was foreseeable that the removal and long-term separation of the plaintiff from his family would give rise to a risk of harm. See Trevorrow $v$ South Australia [No 5] (2007) 98 SASR 136, 358-359.

193 Kevin Rudd, Apology to Australia's Indigenous peoples Australian Government http://www.australia. gov.au/about-australia/our-country/our-people/apology-to-australias-indigenous-peoples (accessed May 1, 2015)

194 Donzelot and Hurley, The Policing of Families, 6-7.

195 Kruger $v$ the Commonwealth, para. 29 (e).

196 Brookings Institution. Institute for Government Research and Lewis Meriam, The Problem of Indian Administration (New York: Johnson Reprint Corp., 1971), 135.

197 Raphael Lemkin and Steven L. Jacobs, Lemkin on Genocide (Lanham: Lexington Books, 2011), 41.

198 Leslie Thielen-Wilson, "Troubling the Path to Decolonization: Indian Residential School Case Law, Genocide, and Settler Illegitimacy," Canadian Journal of Law and Society 29, 2 (2014): 182.

199 Ibid. 